\title{
HOT MIX ASPHALT WITH FLY ASHES FOR DENSE-GRADED SURFACE LAYERS OF RURAL ROADS
}

\author{
ROSA VEROPALUMBO, NUNZIO VISCIONE \& ANNA FORMISANO \\ Department of Civil, Architectural and Environmental Engineering, Federico II University of Naples, Italy
}

\section{ABSTRACT}

This paper aims to define a well-structured methodology that can be applied to perform an effectiveness evaluation of strategies in the road maintenance field by emphasizing local resources use in light of life cycle impact assessment requirements. The experimental study aims to provide a methodological structure to assess when alternative aggregates to limestone can be used in the bituminous mixtures. Properties concerning mechanical, physico-chemical and environmental compatibility features were studied carefully to check fly ash use. A comparative study was carried out on the performance of two mixtures using fly ash and limestone filler. The laboratory program consisted of two phases wherein a first phase mix design is carried out by adopting the Marshall method packaging 6 hot mix asphalt (HMA) mixtures with different bitumen contents between $4 \%$ and $5.25 \%$ by total aggregate weight at $0.25 \%$ increments. In the second phase, additional mechanical properties were investigated concerning final solution of bituminous blend designed in terms of the indirect tensile strength, water sensitivity, complex modulus and cumulative axial strain. The results show that the mixtures prepared with fly ash have better mechanical properties than the mixtures with limestone filler. Furthermore, the mixtures with fly ash also have a high environmental compatibility having recorded negative results of the environmental leaching tests.

Keywords: recycled filler, hot mix asphalt, sustainable pavements.

\section{INTRODUCTION AND LITERATURE REVIEW}

In recent years, the concern for the preservation of the environment and the interest in environmental-related road construction issues have grown faster, becoming a main criterion for the development of socioeconomic policies [1].

Academy and industry are adopting a global approach considering environmental, economic and social aspects in the management of sustainability problems. Environmental issues of sustainable development refer to the depletion of natural resources, global warming, chemical pollution and loss of biodiversity. Based on this, it is necessary that environmental sustainability is evacuate through quantitative measurements, which can support the analysis of environmental impact [2]-[4]. Based on the above rationale, in the construction and use of roads, it is necessary to consider sustainability criteria, because these criteria are a needed contribution to the growth and development of nations, which provides access to employment, social, health, and education services. In addition, the incorporation of environmental aspects guarantees a reduction of impacts, by reducing the use of traditional materials and replacing them with alternative ones [5], [6].

In order to contribute to sustainability in road construction, it has become necessary to increase the research of economically viable solutions with fewer environmental impacts, based on the search for new materials that can partially or completely replace traditional ones [7]. In addition, to being sustainable, the solutions must satisfy both the user's needs and the technical requirements, which means that these materials guarantee a greater strength to the movement of the vehicles [8].

The experimental study concerned the mechanical, physico-chemical and environmental compatibility characterization of the fly ashes deriving from the processing waste of industrial processes (power plant) to replace the limestone filler for the packaging of hot 
mix asphalt. Due to its properties fly ash is a material suitable for use in many asphalt mixtures [9]. This mineral admixture enhances performances and durability of asphalt mixtures, gives economic and environmental benefits, and now is available on Italian market, as a filler responding to EN 13043 [10]-[12]. The study has been implemented in several stages as follows: a) Characterization of dense graded curve; b) Volumetric and mechanical characteristics of asphalt concrete; c) Optimal mix design of mixture packed with different types of fillers (fly ash and limestone filler); d) Analyses of stiffness characteristics of asphalt concrete by dynamic load tests; and e) evaluating of accumulating permanent deformation by creep testing according to EN 12697-25 [13].

The research study showed that the utility of fly ashes materials is that they are hydrophobic, increase stiffness, reduce the amount of asphalt drain down in the mix, improving its resistance, increasing its durability and avoiding the future asphalt stripping.

\section{MATERIALS AND METHOD}

\subsection{Materials}

\subsubsection{Bitumen}

The bitumen which was used to prepare the hot mix asphalt mixes was a 50/70 penetration grade bitumen produced in Italy oil refinery. The basic rheological properties are given in Table 1.

\subsubsection{Fillers}

All aggregates shall be described in terms of aggregate sizes using the designations $d / D$ ( $d$ is the minimum size of aggregates and $D$ is the maximum size of aggregates) except for aggregates added as fillers which shall be specified as filler aggregate and shall comply with the grading requirements specified in Par. 4.3 of UNI EN 13043 [10].

The filler materials used in this study consisted of limestone powder, and fly ash (Fig. 1). The chemical compositions of these fillers have been given in Table 2.

\subsubsection{Limestone filler}

Limestone is a sedimentary stone which is mostly composed of calcium carbonate. It has been commonly used as filler material in HMA. As presented in Table 2 the main LS components were $\mathrm{CaO}, \mathrm{SiO}_{2} . \mathrm{CaO}$ is an alkali composition which contributes to increasing the bitumen aggregate adhesion and improves the HMA resistance against detrimental effects of water which ultimately reduces the potential of aggregate stripping. $\mathrm{SiO}_{2}$ is a pozzolanic compound. Pozzolans consist of silica or silica - aluminates compositions that

Table 1: Physical properties of bitumen.

\begin{tabular}{|l|c|c|c|}
\hline \multirow{2}{*}{ Bitumen properties } & \multicolumn{3}{|c|}{ Results } \\
\cline { 2 - 4 } & Units & Value & Standards \\
\hline Penetration grade & - & $50 / 70$ & - \\
\hline Penetration at $25^{\circ} \mathrm{C}$ & $10^{-4} \mathrm{~m}$ & 52 & UNI EN 1426 \\
\hline Softening point & ${ }^{\circ} \mathrm{C}$ & 49 & UNI EN 1427 \\
\hline Dynamic viscosity at $160^{\circ} \mathrm{C}$ & ${ }^{\circ} \mathrm{C}$ & 0.12 & UNI EN 13702 \\
\hline $\begin{array}{l}\text { Fraas (temperature to which a film of bituminous } \\
\text { binder, of uniform thickness and specified, breaks } \\
\text { down under defined load condition) }\end{array}$ & ${ }^{\circ} \mathrm{C}$ & -10 & UNI EN 12593 \\
\hline
\end{tabular}




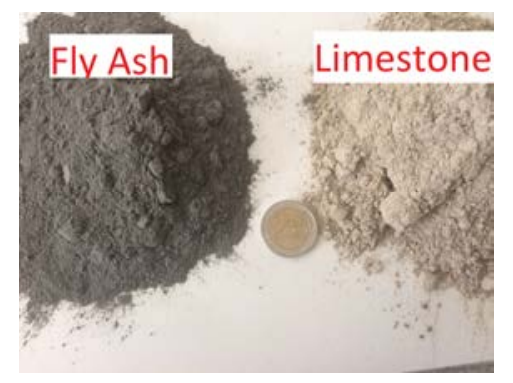

Figure 1: Image of limestone and fly ash filler.

Table 2: Chemical composition of fillers.

\begin{tabular}{|l|c|c|}
\hline \multirow{2}{*}{ Chemical elements } & \multicolumn{2}{|c|}{ Filler type } \\
\cline { 2 - 3 } & Limestone & Fly ash \\
\hline $\mathrm{Ca}$ & $66.7 \%$ & $5.1 \%$ \\
\hline $\mathrm{Fe}$ & $4.2 \%$ & $25.5 \%$ \\
\hline $\mathrm{Si}$ & $26.3 \%$ & $69.3 \%$ \\
\hline $\mathrm{Mg}$ & $2.74 \%$ & $0.00 \%$ \\
\hline $\mathrm{Co}$ & $0.00 \%$ & $0.01 \%$ \\
\hline $\mathrm{Mn}$ & $0.01 \%$ & $0.01 \%$ \\
\hline $\mathrm{Ni}$ & $0.01 \%$ & $0.00 \%$ \\
\hline $\mathrm{Cu}$ & $0.01 \%$ & $0.01 \%$ \\
\hline $\mathrm{Zn}$ & $0.01 \%$ & $0.04 \%$ \\
\hline Other & $0.01 \%$ & $0.02 \%$ \\
\hline
\end{tabular}

have slight cohesion, but in a soft powder form and with the presence of water and lime can produce cemented compounds. However, there are also pozzolans which have selfcementing properties.

\subsubsection{Fly ash}

Fly ash is a coal combustion product, part of a set of products that makes up the most abundant waste materials worldwide. If not collected, this waste material is blown out with the flue gas in a coal-fired power plant. This ash exists after combustion because ash adheres to coal, making up between $1-15 \%$ of its weight. The ash remains after combustion and about $90 \%$ of the ash is fly ash while $10 \%$ is bottom ash. In this study were used fly ash, their chemical composition has showed in Table 2. To verify that no harmful substances are released by fly ash filler, leaching test was carried out. The results are reported in Table 3, which also presents the limits defined by Italian law D.M. 05.02.98. The analysis showed that fly ash did not release any metallic pollutants in water, so it confirms that this type of material could be used as alternative material in hot mix asphalt production.

\subsubsection{Aggregates}

Hot mix asphalt (HMA) concrete is a combination of aggregate and asphalt cement. The aggregate acts as the structural skeleton of the pavement and the asphalt cement as the glue of the mixture. The mineral aggregate, including coarse and fine particles in asphalt paving 
Table 3: Results from leaching test.

\begin{tabular}{|l|c|c|c|}
\hline Parameter & Units & Results & Law limits \\
\hline Phenol & $\mathrm{mg} / \mathrm{l}$ & $<0.01$ & 100 \\
\hline Arsenic & $\mathrm{mg} / \mathrm{l}$ & $<0.01$ & 0.050 \\
\hline Barium & $\mathrm{mg} / \mathrm{l}$ & $<0.01$ & 1.0 \\
\hline Beryllium & $\mu \mathrm{g} / \mathrm{l}$ & $<0.01$ & 10 \\
\hline Cadmium & $\mathrm{mg} / \mathrm{l}$ & $<0.01$ & 0.005 \\
\hline Cobalt & $\mathrm{mg} / \mathrm{l}$ & 0.06 & 0.25 \\
\hline Total chromium & $\mathrm{mg} / \mathrm{l}$ & $<0.01$ & 0.050 \\
\hline Copper & $\mathrm{mg} / \mathrm{l}$ & $<0.01$ & 0.05 \\
\hline Mercury & $\mathrm{mg} / \mathrm{l}$ & $<0.001$ & 0.001 \\
\hline Molybdenum & $\mathrm{mg} / \mathrm{l}$ & $<0.01$ & 100 \\
\hline Nickel & $\mathrm{mg} / \mathrm{l}$ & $<0.01$ & 0.010 \\
\hline Vanadium & $\mathrm{mg} / \mathrm{l}$ & 0.02 & 0.25 \\
\hline Lead & $\mathrm{mg} / \mathrm{l}$ & $<0.01$ & 0.050 \\
\hline Antimony & $\mathrm{mg} / \mathrm{l}$ & $<0.01$ & 100 \\
\hline Selenium & $\mathrm{mg} / \mathrm{l}$ & $<0.01$ & 0.010 \\
\hline Zinc & $\mathrm{mg} / \mathrm{l}$ & 0.33 & 3.0 \\
\hline Chloride & $\mathrm{mg} / \mathrm{l}$ & 35.45 & 100 \\
\hline Nitrate & $\mathrm{mg} / \mathrm{l}$ & 0.09 & 50 \\
\hline Fluoride & $\mathrm{mg} / \mathrm{l}$ & $<0.01$ & 1.5 \\
\hline Cyanide & $\mathrm{mg} / \mathrm{l}$ & $<0.01$ & 0.050 \\
\hline Sulphate & $\mathrm{mg} / \mathrm{l}$ & 4.4 & 250 \\
\hline DOC & $\mathrm{mg} / \mathrm{l}$ & 6.1 & 100 \\
\hline TDS & $\mathrm{mg} / \mathrm{l}$ & 1.29 & 100 \\
\hline Asbestos & $\mathrm{mg} / \mathrm{l}$ & $<0.01$ & 30 \\
\hline Ph & $\mathrm{mg} / \mathrm{l}$ & 9.73 & 12 \\
\hline COD & $\mathrm{mg} / \mathrm{l}$ & 5.8 & 30 \\
\hline Phenol & $\mathrm{mg} / \mathrm{l}$ & $<0.01$ & 100 \\
\hline & & & \\
\hline
\end{tabular}

mixtures, encompasses approximately $90 \%$ of volume of HMA. In this study, two different binder layer HMA mixtures were prepared. For one of them, fly ash filler totally substituted the weight of the traditional limestone filler, which was used in the second mixture as reference. In this research crushed and sharp-edged aggregates were used to prepare the asphalt mixes. The mix design tested in this study was a dense-graded wearing course mix, with $19 \mathrm{~mm}$ nominal maximum size. The gradation is reported in Fig. 2 and Table 4. It is highlighted that even if the two fillers are different they have the same gradation with the same filler content in the mix with a percentage of $3 \%$.

\subsection{Method}

\subsubsection{Mix design}

To determine the optimum bitumen content six different mixes were prepared with different bitumen content between $4 \%$ and $5.25 \%$ by total aggregate weight at $0.25 \%$ increments for mix containing fly ash, whereas five mixes with different bitumen content between $4.75 \%$ and $5.75 \%$ for mix containing limestone filler. For each mix, tests were carried out on four cylindrical specimens with $100 \mathrm{~mm}$ diameter, prepared with impact compactor (EN 12697- 


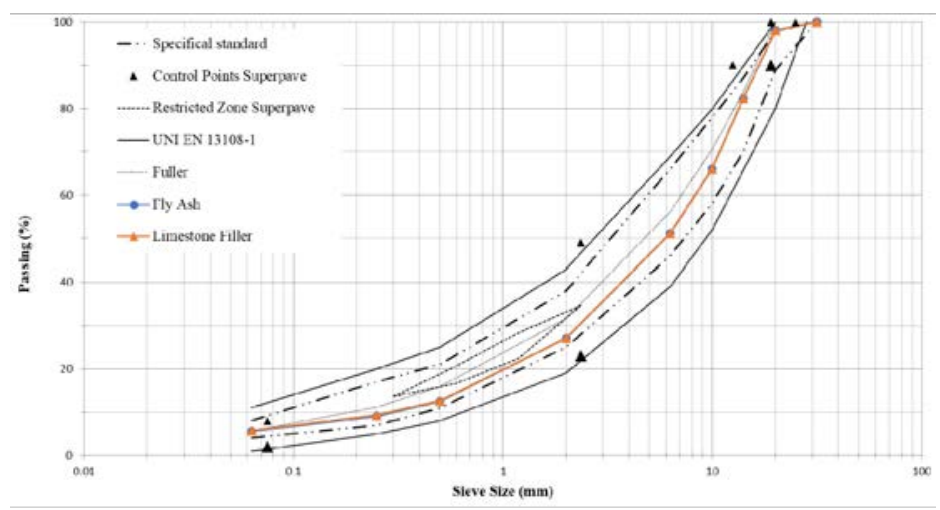

Figure 2: Grading curves for bituminous mixtures.

Table 4: Aggregate percentages.

\begin{tabular}{|l|c|c|c|}
\hline \multirow{2}{*}{ Aggregate type } & \multicolumn{3}{|c|}{ Mixture type } \\
\cline { 2 - 4 } & Units & Limestone & Fly ash \\
\hline Limestone No 2 & $\%$ & 23 & 23 \\
\hline Limestone No 1 & $\%$ & 29 & 29 \\
\hline Limestone 3/6 & $\%$ & 13 & 13 \\
\hline Limestone dust & $\%$ & 32 & 32 \\
\hline Filler & $\%$ & 3 & 3 \\
\hline
\end{tabular}

30 [14]) for a binder layer. To determine the optimum bitumen content Marshall stability test were evaluated according to EN 12697-34 [15].

\subsubsection{Marshall stability test}

Marshall stability and flow were based on the EN 12697-34 [15], conducted at $60^{\circ} \mathrm{C}$ and a loading rate of $50 \mathrm{~mm} / \mathrm{min}$ for each mix type. Marshall stability shows the ability of asphalt concrete to resist against shoving and rutting. Flow shows the ability of asphalt concrete to resist gradual settlement and deformation without cracking.

Figs 3 and 4 represent the value of Marshall stability and Marshall flow respectively for mixes with fly ash and limestone filler. The value of the optimal percentage of bitumen has been chosen in correspondence with the maximum Marshall stability reached by the mixture, according to literature, and it is possible to notice that the optimum bitumen content in the mixture containing fly ash, $4.75 \%$, is lower than the mixture containing limestone filler, 5.25\%. About the Marshall flow, although the two mixtures showed different bitumen content, the value assumed at the optimum is almost the same.

\subsubsection{Percentage of voids}

The optimum bitumen content was validated by the volumetric characterization of the mixture, in terms of air voids by means of the SSD (Saturated Surface Dry) procedure (EN 12697-06 [16]), that are a procedure for measuring the bulk density of dense-graded bituminous specimens [17]. The percentage of voids for both mixtures was found to fall within the range defined by the reference Italian specification. In particular, the percentage 


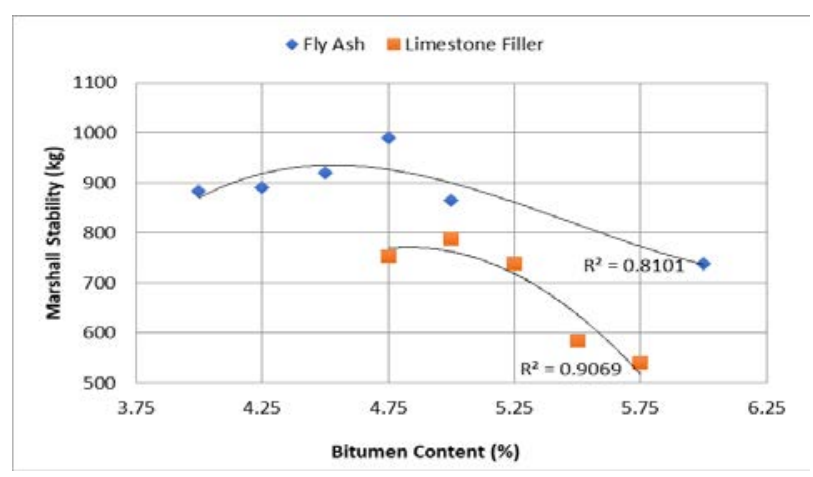

Figure 3: Relation between bitumen content and Marshall stability.

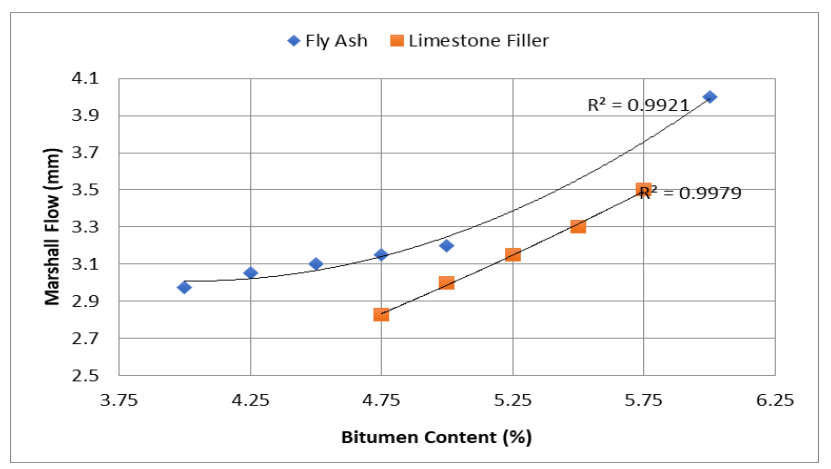

Figure 4: Relation between bitumen content and Marshall flow.

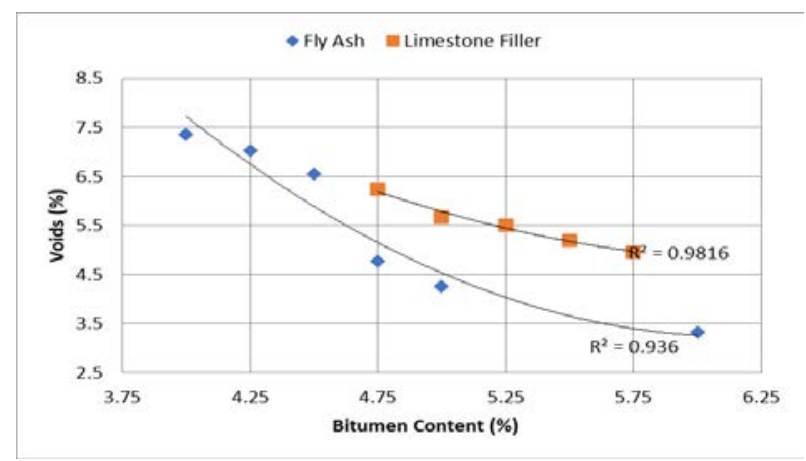

Figure 5: Relation between bitumen content and percentage of voids.

of voids was higher for mixture containing limestone filler compared to mixture containing fly ash, although the latter showed a lower optimum bitumen content. The relation between bitumen content and percentage of voids are showed in Fig. 5.

Table 5 shows the values of Marshall stability, Marshall flow and percentage of voids of optimum binder content mixtures. 
Table 5: Mechanical properties of optimum mixtures.

\begin{tabular}{|l|c|c|c|c|}
\hline \multirow{2}{*}{ Mixture type } & \multicolumn{4}{|c|}{ Table column heading } \\
\cline { 2 - 5 } & $\begin{array}{c}\text { Bitumen } \\
\text { content }\end{array}$ & $\begin{array}{c}\text { Marshall } \\
\text { stability }\end{array}$ & $\begin{array}{c}\text { Marshall } \\
\text { flow }\end{array}$ & $\begin{array}{c}\text { Percentage } \\
\text { of voids }\end{array}$ \\
\hline Limestone & $5.25 \%$ & $738 \mathrm{~kg}$ & $3.15 \mathrm{~mm}$ & $5.51 \%$ \\
\hline Fly ash & $4.75 \%$ & $990 \mathrm{~kg}$ & $3.15 \mathrm{~mm}$ & $4.78 \%$ \\
\hline
\end{tabular}

\section{RESULTS}

\subsection{Evaluation of ITS and ITSR}

The static mechanical characterization is conducted by Indirect Tensile Strength (ITS) test both in dry and wet condition. Three specimens for each mixture were first conditioned at $25^{\circ} \mathrm{C}$ for two hours and then tested according to EN 12697-23 [18]. During the ITS test, a cylindrical sample is subjected to compressive loads between two loading strips which create tensile stress along the vertical diametric plane causing a splitting failure. The results are shown in Table 6 . The indirect tensile strength for mixtures containing fly ash was proved to be lower than limestone filler. At the same time, for a more accurate evaluation of the indirect tensile strength, other three samples for each mixture were kept in a water bath for 72 hours at $40^{\circ} \mathrm{C}$ and then tested according to EN12697-12 [19]. The evaluation of ITSR (Indirect Tensile Strength Ratio) index has been operated by the following equation:

$$
I T S R=\frac{I T S_{w e t}}{I T S_{d r y}} \cdot 100
$$

It is well-known that water sensitivity evaluation is essential when studying asphalt recycled mixtures, since this property is directly related to the behaviour and durability of these materials. The results (Fig. 6 and Table 6), in terms of ITSR, shows that there is not a substantial different in the reduction of ITS in wet condition between the two mixtures. The reduction of ITS is lower than the limit imposed by the technical standard taken as reference $(<30 \%)$.

\subsection{Indirect tensile stiffness modulus}

The characterization of the mixtures needs an additional parameter for the representation of the mechanical response of the material. The mixtures have a viscoelastic/viscoplastic behaviour and everything depends on the application time of the load and the operating temperature. To evaluate this behaviour the Stiffness Modulus (or complex modulus) has been determined according to ANNEX D of EN 12697-26 [20] in a direct tensile configuration. The tests were made on compacted bituminous material under a sinusoidal loading, using specimens (obtained by gyratory compactor according to EN 12697-31 [21]) that had:

- a diameter $(\phi)$ between $50 \mathrm{~mm}$ and $160 \mathrm{~mm}$ inclusive and greater than or equal to four times $\mathrm{D}$; the tolerance on the diameter in the measurement area shall be less than $0.5 \mathrm{~mm}$;

- $\quad$ a length $(\mathrm{H})$ between 1.8 and 3 times the specimen diameter. 
Table 6: ITS results.

\begin{tabular}{|l|c|c|c|}
\hline \multirow{2}{*}{ Mixture type } & \multicolumn{3}{|c|}{ Test type } \\
\cline { 2 - 4 } & ITS wet & ITS dry & ITSR \\
\hline Limestone & $0.95 \mathrm{~kg}$ & $0.92 \mathrm{~kg}$ & $96.36 \%$ \\
\hline Fly ash & $0.92 \mathrm{~kg}$ & $0.88 \mathrm{~kg}$ & $95.89 \%$ \\
\hline
\end{tabular}

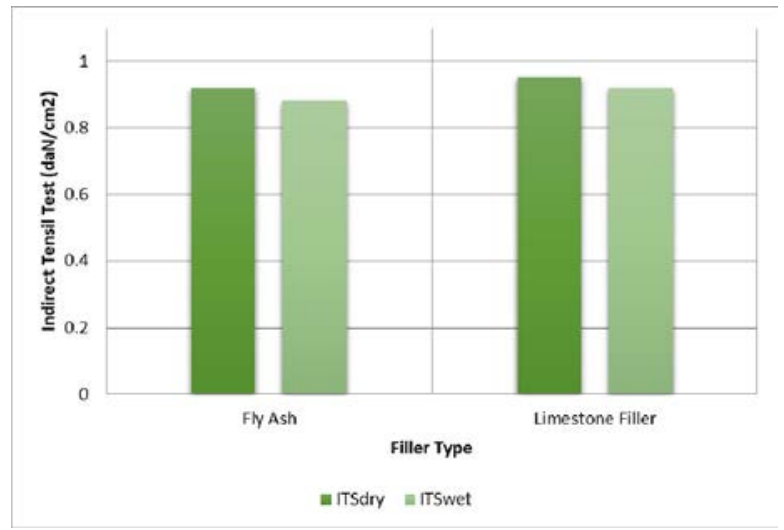

Figure 6: Relation between ITS and ITSR.

A sinusoidal strain (eqn (2)) was applied on a cylindrical sample glued on two steel plates screwed to the loading rig. $\varepsilon_{0}$ should be $\leq 25 \cdot 10^{-6}$ to be in the linear range of the bituminous mixture. With measured $F_{0}$ and phase angle $\Phi$, the complex modulus is calculated at different temperatures and frequencies.

$$
\varepsilon=\varepsilon_{0} \times \sin (\omega \mathrm{t}),
$$

where:

- $\quad \varepsilon_{0}$ is the initial strain;

- $\quad \omega$ is the test frequency, in hertz $(\mathrm{Hz})$;

- $t$ is the loading time, in seconds (s).

For each mixture 4 cylindrical specimens having a height of $200 \mathrm{~mm}$ were packaged by means of the gyratory compactor (according to EN 12697-31 [21]), subjected to a normal oscillating tension according to established amplitude and frequency. The complex modulus was determined at four different temperatures, $10^{\circ} \mathrm{C}, 25^{\circ} \mathrm{C}$ and $40^{\circ} \mathrm{C}$ and three different frequencies, $1 \mathrm{~Hz}, 5 \mathrm{~Hz}$ and $10 \mathrm{~Hz}$.

The data of mixture containing fly ash and limestone filler in different curing times are respectively shown in Table 7.

It is seen that complex modulus of fly ash increases with increasing frequency and decreases with increasing temperature. The same is show for the mixtures containing limestone filler. Based on the time-temperature superposition principle $\left(25^{\circ} \mathrm{C}\right)$, the master curves are obtained using shift factors $(\mathrm{a}(\mathrm{T}))$ that are calculated according to eqn (3): 
Table 7: Complex modulus results.

\begin{tabular}{|c|c|c|c|}
\hline \multicolumn{2}{|c|}{} & \multicolumn{2}{c|}{ Complex modulus value $(\mathrm{MPa})$} \\
\hline Frequency $(\mathrm{Hz})$ & Temperature $\left({ }^{\circ} \mathrm{C}\right)$ & Limestone & Fly ash \\
\hline 1 & 10 & 6,620 & 8,960 \\
\hline 1 & 25 & 2,007 & 2,963 \\
\hline 1 & 40 & 367 & 391 \\
\hline 5 & 10 & 10,534 & 11,465 \\
\hline 5 & 25 & 4,062 & 5,493 \\
\hline 5 & 40 & 825 & 994 \\
\hline 10 & 10 & 10,787 & 12,025 \\
\hline 10 & 25 & 5,365 & 6,568 \\
\hline 10 & 40 & 1,125 & 1,361 \\
\hline
\end{tabular}

$$
\log \frac{a(T)}{a\left(T_{0}\right)}=\frac{-C_{1} \cdot\left(T-T_{0}\right)}{C_{2}+T-T_{0}}
$$

where:

- $\quad a(T)$ and $a\left(T_{0}\right)$ are the shift factors at temperature $T$ and $T_{0}$;

- $\quad T$ is the temperature of reference;

- $T_{0}$ is the temperature at $25^{\circ}$;

- $\quad C_{1}$ and $C_{2}$ are constants that depend by nature of the material.

The master curves of complex modulus of mixtures containing limestone filler is obtained as a comparison. It is seen in Fig. 7 that the complex modulus of fly ash at elevated temperatures and low frequencies is higher than the limestone filler, while for higher frequencies and low temperatures the complex modulus of the two mixtures tend to overlap. Hence, from these results it can be deduced that mixtures containing fly ashes lend themselves well to elevated temperatures and low frequencies in terms of stiffness.

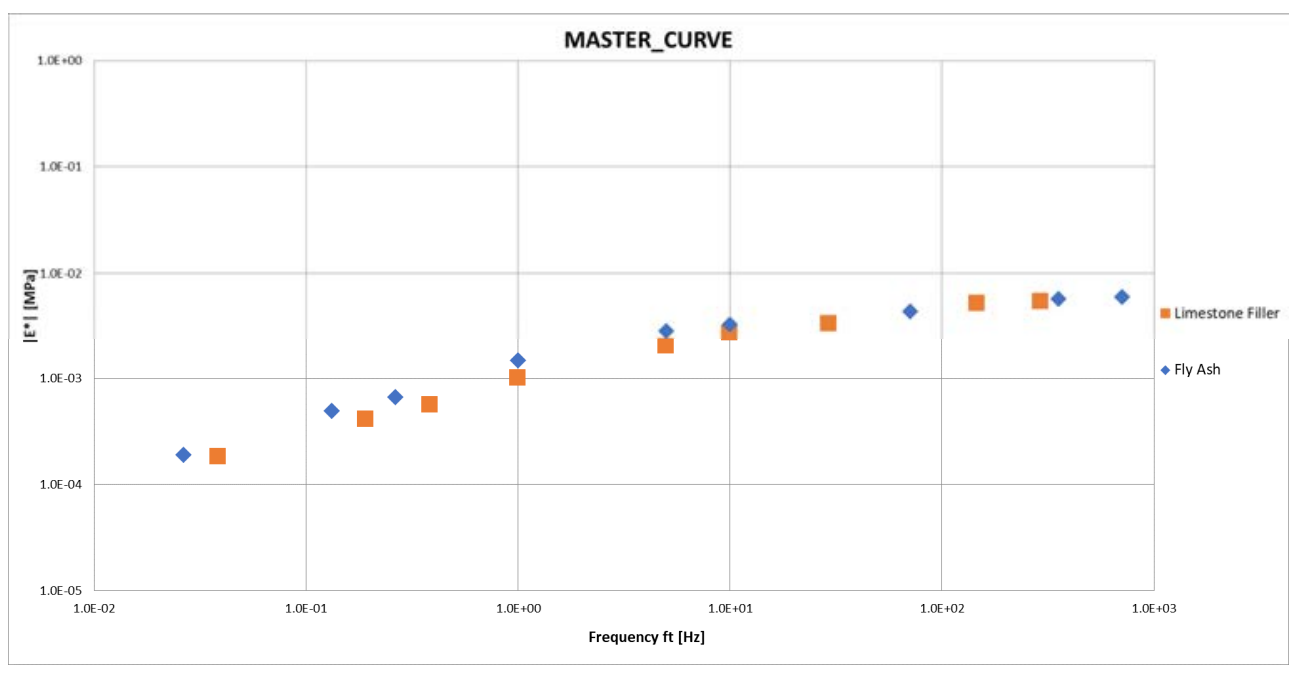

Figure 7: Master curves results. 


\subsection{Repeated load axial test}

Resistance to permanent deformations (or Creep test) in asphalt concrete can be evaluated using the Repeated Load Axial Test (RLAT), in a direct uniaxial compression test configuration (EN 12697-25 [13]). The test has been undertaken on a cylindrical specimen (maintained at elevated conditioning temperature) placed between two plan parallel loading platens (Fig. 8). The cyclic axial pressure has been obtained as a haversinusoidal pressure $\sigma_{\mathrm{a}}(\mathrm{t})$, with amplitude $\sigma_{\mathrm{v}}$. The resulting total axial test pressure, $\sigma_{\mathrm{A}}(\mathrm{t})$, was:

$$
\sigma_{\mathrm{A}}(\mathrm{t})=\sigma_{\mathrm{C}}+\sigma_{\mathrm{a}}(\mathrm{t})=\sigma_{\mathrm{C}}+\sigma_{\mathrm{V}} \cdot(1+\sin (2 \pi \cdot \mathrm{f} \cdot \mathrm{t})),
$$

where:

- $\quad \sigma_{\mathrm{c}}$ is a confining stress, in kilopascal $(\mathrm{kPa})$;

- $\sigma_{\mathrm{a}}(\mathrm{t})$ is the cyclic axial pressure as a function of time, in kilopascal $(\mathrm{kPa})$;

- $\sigma_{\mathrm{v}}$ is the amplitude of the haversinusoidal pressure, in kilopascal $(\mathrm{kPa})$;

- $\mathrm{f}$ is the frequency, in hertz $(\mathrm{Hz})$;

- $t$ is the time.

During the test the change in height of the specimen is measured at specified numbers of load applications. From this, the cumulative axial strain, $\varepsilon_{\mathrm{n}}$, (permanent deformation) of the test specimen is determined as a function of the number of load applications. From the numerous results that can be obtained in this test, the total accumulated strain and the average strain can be effective in evaluating the potential permanent deformation.

The specimen was subjected to a confining pressure, $\sigma_{\mathrm{c}}$ of $150 \mathrm{kN}$ and a $\sigma_{V}$ of $350 \mathrm{kN}$. Fig. 9 shows the accumulated strain of the two mixtures in function of number of cycles. It can be seen that near the first 500 loading cycles the two mixtures have an almost similar deformation, after increasing with the loading cycles the deformation of the mixture with limestone filler increases dramatically relative to the fly ash. In particular, the accumulated strain of fly ash after 3000 load cycles remains fairly constant, unlike the limestone filler where it continues to show an increase in the accumulated axial strain even at the end of the load cycles examined. Furthermore, during the test the change in height of the specimen is measured at specified numbers of load applications. From this, the cumulative axial strain, \&n, for fly ash was $7.5 \%$ vs. $10 \%$ of limestone filler. Once again, with a dynamic test like the creep, the improvement in terms of stiffness of mixtures containing fly ash is confirmed.

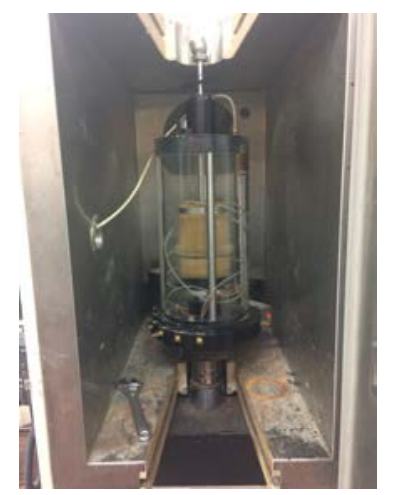

Figure 8: RLAT test method. 


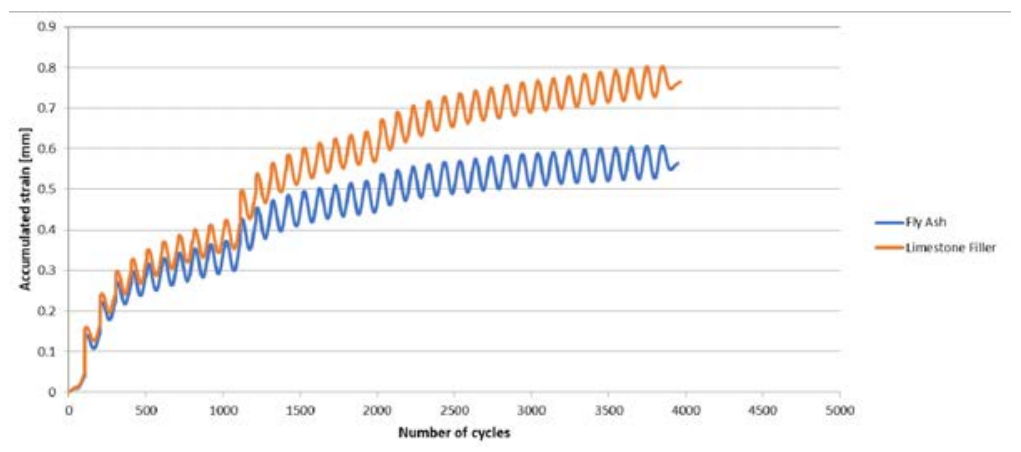

Figure 9: Repeated load axial test results.

\section{CONCLUSIONS}

The aim of the present research was to evaluate the possibility of replacing the limestone filler for the design of HMA for the binder layer of rural roads with material derived from waste of industrial processes such as fly ash. In particular, volumetric and mechanical characteristics were assessed in compliance with the limits suggested by the reference Italian specifications for the type of road under examination and the whole was accompanied by an environmental assessment carried out by means leaching test. According to the experimental results presented in this study, the following conclusion can be drawn for the laboratory phase:

- The amount of bitumen used for the mix design containing fly ash was $0.5 \%$ lower than those containing limestone filler. In addition, better performance in terms of Marshall stiffness in the case of mixtures made with fly ash reaching values higher than $25 \%$ compared to limestone filler.

- In terms of water sensitivity, both mixtures have the same ITS reduction around $4 \%$.

- Very high complex modulus for mixtures containing fly ash and stiffness confirmed by the creep test where at 3000 load cycles the mixture was found to settle its deformations unlike the limestone filler where at the end of the loading cycles it continued to want to deform.

According to these results, therefore, it is possible to validate the use of fly ashes for the construction of a binder layer for rural roads which, at the same granulometric curve improves the mechanical parameters. At the same time an economic evaluation of road pavements is as important as their technical and structural design. For this reason, the use of fly ashes in HMA for a binder layer for rural road is also approved in terms of costs because:

- $\quad$ the percentage of bitumen used is lower;

- in environmental terms, since it eliminates the transfer to landfill of the fly ash as waste but characterizes it as a second raw material, used for HMA.

To confirm the reduction of saving production costs and materials disposal during a reconstruction of the pavement layers, the environmental impact will be investigated in compliance with ISO 2000 that will help to identify the strengths and weaknesses of the processes evaluated. 


\section{REFERENCES}

[1] Balaguera, A., Carvajal, G.I., Albertí, J. \& Fullana-i-Palmer, P., Life cycle assessment of road construction alternative materials: A literature review. Resources, Conservation and Recycling, 132, pp. 37-48. 2018.

[2] Moretti, L., Di Mascio, P. \& D'Andrea, A., Environmental impact assessment of road asphalt pavements. Modern Applied Science, 7(11), p. 1, 2013.

[3] Dell'Acqua, G., De Luca, M. \& Russo, F., Procedure for making paving decisions with cluster and multicriteria analysis. Journal of the Transportation Research Board, 2282, pp. 57-66, 2012. DOI: 10.3141/2282-07.

[4] Dell'Acqua, G. \& Russo, F., Road performance evaluation using geometric consistency and pavement distress data. Journal of the Transportation Research Board, 2203(1), pp. 194-202, 2011. DOI: 10.3141/2203-24.

[5] Topini, D., Toraldo, E., Andena, L. \& Mariani, E., Use of recycled fillers in bituminous mixtures for road pavements. Construction and Building Materials, 159, pp. 189-197, 2018.

[6] Sangiorgi, C., Tataranni, P., Simone, A., Vignali, V., Lantieri, C., \& Dondi, G., A laboratory and filed evaluation of Cold Recycled Mixture for base layer entirely made with Reclaimed Asphalt Pavement. Construction and Building Materials, 138, pp. 232-239, 2017.

[7] Sangiorgi, C., Tataranni, P., Simone, A., Vignali, V., Lantieri, C. \& Dondi, G., Waste bleaching clays as fillers in hot bituminous mixtures. Construction and Building Materials, 73, pp. 320-325, 2014.

[8] Moretti, L., Technical and economic sustainability of concrete pavements. Modern Applied Science, 8(3), p. 1, 2014.

[9] Bocci, E., Use of ladle furnace slag as filler in hot asphalt mixtures. Construction and Building Materials, 161, pp. 156-164, 2018.

[10] EN 13043, Aggregates for bituminous mixtures and surface treatments for roads, airfields and other trafficked areas, 2004.

[11] Chen, M., Lin, J. \& Wu, S., Potential of recycled fine aggregates powder as filler in asphalt mixture. Construction and Building Materials, 25(10), pp. 3909-3914, 2011.

[12] Modarres, A. \& Rahmanzadeh, M., Application of coal waste powder as filler in hot mix asphalt. Construction and Building Materials, 66, pp. 476-483, 2014.

[13] EN 12697-25, Bituminous mixtures. Test methods for hot mix asphalt. Part 25: Cyclic compression test, 2005.

[14] EN 12697-30, Bituminous mixtures. Test methods for hot mix asphalt. Part 30: Specimen preparation by impact compactor, 2012.

[15] EN 12697-34, Bituminous mixtures. Test methods for hot mix asphalt. Part 34: Marshall test, 2012.

[16] EN 12697-06, Bituminous mixtures. Test methods for hot mix asphalt. Part 6: Determination of bulk density of bituminous specimens, 2003.

[17] Russo, F., Biancardo, S.A., Formisano, A. \& Dell'Acqua, G., Predicting percent air voids content in compacted bituminous hot mixture specimens by varying the energy laboratory compaction and the bulk density assessment method. Construction and Building Materials, 164, pp. 508-524, 2018.

[18] EN 12697-23, Bituminous mixtures. Test methods for hot mix asphalt. Part 23: Determination of the indirect tensile strength of bituminous specimens, 2006.

[19] EN 12697-12, Bituminous mixtures. Test methods for hot mix asphalt. Determination of the water sensitivity of bituminous specimens, 2004. 
[20] EN 12697-26, Bituminous mixtures. Test methods for hot mix asphalt. Part 26: Stiffness, 2004.

[21] EN 12697-31, Bituminous mixtures. Test methods for hot mix asphalt. Part 31: Specimen preparation by gyratory compactor, 2004. 